

\title{
An Enteral Leucine Supply Modulates Human Duodenal Mucosal Proteome and Decreases the Expression of Enzymes Involved in Fatty Acid Beta-Oxidation
}

\author{
Alexis Goichon, Philippe Chan, Stéphane Lecleire, Aude Coquard,
} Anne-Françoise Cailleux, Stéphane Walrand, Eric Lerebours, David Vaudry, Pierre Déchelotte, Moïse Coëffier

\section{To cite this version:}

Alexis Goichon, Philippe Chan, Stéphane Lecleire, Aude Coquard, Anne-Françoise Cailleux, et al.. An Enteral Leucine Supply Modulates Human Duodenal Mucosal Proteome and Decreases the Expression of Enzymes Involved in Fatty Acid Beta-Oxidation. Journal of Proteomics, 2013, 78, pp.535-544. 10.1016/j.jprot.2012.10.024 . hal-02305179

HAL Id: hal-02305179

https://hal.science/hal-02305179

Submitted on 29 May 2020

HAL is a multi-disciplinary open access archive for the deposit and dissemination of scientific research documents, whether they are published or not. The documents may come from teaching and research institutions in France or abroad, or from public or private research centers.
L'archive ouverte pluridisciplinaire HAL, est destinée au dépôt et à la diffusion de documents scientifiques de niveau recherche, publiés ou non, émanant des établissements d'enseignement et de recherche français ou étrangers, des laboratoires publics ou privés. 


\title{
An enteral leucine supply modulates human duodenal mucosal proteome and decreases the expression of enzymes involved in fatty acid beta-oxidation
}

\begin{abstract}
Alexis Goichon ${ }^{1,2}$, Philippe Chan ${ }^{2,3}$, Stéphane Lecleire ${ }^{1,2,4}$, Aude Coquard ${ }^{5}$, Anne-Françoise Cailleux $^{2,6}$, Stéphane Walrand ${ }^{7}$, Eric Lerebours ${ }^{1,2,4}$, David Vaudry ${ }^{2,3,8}$, Pierre Déchelotte ${ }^{1,2,9}$, and Moïse Coëffier ${ }^{1,2,9}$
\end{abstract}

From

${ }^{1}$ INSERM unit 1073, Rouen, France;

${ }^{2}$ Rouen university, Institute for Research and Innovation in Biomedicine, Rouen, France;

${ }^{3}$ Platform in proteomics PISSARO, Mont-Saint-Aignan, France;

${ }^{4}$ Rouen University Hospital, Department of Gastroenterology, Rouen, France;

${ }^{5}$ Rouen University Hospital, Department of Pharmacy, Rouen, France;

${ }^{6}$ Clinical Investigation Center CIC 0204-INSERM, Rouen, France;

${ }^{7}$ INRA, UMR 1019, UNH, CRNH Auvergne, Clermont-Ferrand, France;

${ }^{8}$ INSERM unit 982, Mont-Saint-Aignan, France;

${ }^{9}$ Rouen University Hospital, Nutrition unit, Rouen, France.

\section{$\underline{\text { To whom correspondence should be addressed: }}$}

Moïse Coëffier, INSERM unit 1073, University of Rouen, 22 boulevard Gambetta, 76183 Rouen Cedex, France.

Phone: +33-2-35-14-82-40, Fax: +33-2-35-14-82-26, Email: moise.coeffier@univ-rouen.fr 
8

9

1

\section{ABSTRACT}

Leucine is well known to regulate protein metabolism in muscle. We recently reported that enteral leucine infusion decreased proteasome activity in human duodenal mucosa and enhanced intestinal cell proliferation, but its effects on gut proteome remain unknown. Therefore, we aimed to assess the effects of an enteral leucine infusion on the whole proteome of duodenal mucosa. In this work, 5 healthy volunteers received for $5 \mathrm{~h}$, on 2 occasions and in random order, an enteral supply of maltodextrins $\left(0.25 \mathrm{~g} \cdot \mathrm{kg}^{-1} \cdot \mathrm{h}^{-1}\right)$ or maltodextrins supplemented with leucine $\left(0.035 \mathrm{~g} \cdot \mathrm{kg}^{-1} \cdot \mathrm{h}^{-1}\right)$. At the end of infusion, endoscopic duodenal biopsy samples were collected and analyzed by 2D-PAGE. Eleven protein spots were differentially and significantly $(P<0.05)$ expressed in response to the leucine-supplemented maltodextrins compared with maltodextrins alone. Forty percent of identified proteins by mass spectrometry were located in mitochondria. Four proteins were involved in lipid metabolism: HADHA, ACADVL and CPT2 expressions were reduced, whereas FABP1 expression was increased. In addition, the expression of DHA kinase involved in glycerol metabolism was also downregulated. Finally, leucine supplementation altered the duodenal mucosal proteome by regulating the expression of several enzymes mainly involved in lipid metabolism. These results suggest that leucine supplementation may slowdown fatty acid beta-oxidation in human duodenal mucosa.

0

\section{KEYWORDS}

Enteral nutrition, leucine, duodenum, proteome, fatty acid oxidation. 


\section{INTRODUCTION}

Gut barrier plays a major role in the prevention of local and systemic infections as firstline defense against antigens derived from ingested food, xenobiotics, bacteria and viruses. Enhanced intestinal permeability is involved in several chronic inflammatory diseases or in infectious complications [1-3]. Intestinal barrier is partly regulated by a balance between protein synthesis and degradation, and protein fractional synthesis rate (FSR) approached 50\% per day in human duodenal mucosa [4]. Previous studies reported that the administration of specific nutrients, i.e. glutamine or arginine, can modulate intestinal protein metabolism [4-9].

Although the effects of leucine are well established in muscle, i.e. stimulation of protein synthesis $[10,11]$ and reduction of proteasome-mediated proteolysis [12], its effects on intestinal protein metabolism have been poorly documented. In intestinal epithelial cells, leucine has been shown to activate the mammalian target of rapamycin (mTOR) signaling pathway which is involved in the regulation of protein synthesis [13-15]. In neonatal pigs, Murgas Torrazza et al reported that leucine supplementation of a low-protein diets stimulated jejunal mucosal protein synthesis through the activation of the mTOR effectors [16]. A similar study showed that dietary supplementation with $0.27 \%$ leucine increased protein synthesis in proximal and distal small intestine but not in the colon of weaning pigs [17]. In contrast, we recently reported that a high dose of leucine affected neither duodenal mucosal protein FSR nor mTOR pathway but decreased proteasome activity in human duodenal mucosa [18]. In addition, leucine enhanced intestinal cell proliferation through the PI3K/Akt/GSK-3 $\alpha / \beta$-catenin pathway [18]. However, the

4 influence of enteral leucine supplementation on human gut proteome in healthy conditions remains unknown. 
Thus, the aim of this experimental study was to assess the effects of an acute enteral

47 leucine supply on the expression of duodenal mucosal proteins and to elucidate the leucine-

48 modulated metabolic pathways.

49 
1



\section{SUBJECTS AND METHODS}

\section{Clinical protocol and ethical authorizations}

The current study was performed in accordance with the guidelines of the Center for Clinical Investigations, after approval by the local ethics committee (North-west I, France). Five healthy volunteers (3 M, $2 \mathrm{~F}$ ) gave their written informed consent for this study. The subjects were in good general health and had no hepatic, renal, or cardiac dysfunction or any medical or surgical digestive history. The volunteers had a mean ( \pm SEM) age of $21.9 \pm 4.8$ y and body mass index (in $\left.\mathrm{kg} / \mathrm{m}^{2}\right)$ of $22.2 \pm 0.6$.

During the three days before the experimental trial, all subjects consumed a controlled diet providing $30 \mathrm{kcal}$ and $0.9 \mathrm{~g}$ protein. $\mathrm{kg}^{-1} \cdot \mathrm{d}^{-1}$. On the morning of the study after an overnight fasting, the subjects received over $5 \mathrm{~h}$, on two occasions, and in a random order by a nasogastric feeding tube either maltodextrins (control condition: $0.25 \mathrm{~g} \cdot \mathrm{kg}^{-1} \cdot \mathrm{h}^{-1}$; Lactalis Nutrition Santé, Torcé, France) or maltodextrins plus leucine (leucine condition: $0.035 \mathrm{~g}$ free L-leucine. $\mathrm{kg}^{-1} \cdot \mathrm{h}^{-1}$; Cooper, Melun, France). The infusion rate was $3.5 \mathrm{~mL} \cdot \mathrm{kg}^{-1} \cdot \mathrm{h}^{-1}$. The dose of leucine supplied was chosen as a compromise between the dose used in former studies on muscle proteins and a higher dose needed to affect the very high protein turnover rate of the intestinal mucosa. To avoid a comparison of leucine supply to a fasted status, we compared maltodextrins supplemented with leucine with maltodextrins alone. Thirty minutes after the end of infusion, endoscopic biopsy samples were collected from the duodenal mucosa, immediately snap-frozen in liquid nitrogen, and stored at $-80^{\circ} \mathrm{C}$ until analysis.

\section{Protein extraction and 2DE-separation}


Protein extraction and 2DE-separation were performed as previously described [19]. Briefly, endoscopic samples were homogenized in ice-cold lysis buffer containing $7 \mathrm{~mol} \mathrm{urea/L,} 2 \mathrm{~mol}$ thiourea/L, 4\% (wt:vol) CHAPS, $50 \mathrm{mmol}$ dithiothreitol/L, $25 \mathrm{mmol}$ spermine tetrahydrochloride/L, 0.5\% (vol:vol) IPG buffer pH 3-10 NL (GE Healthcare), and a protease inhibitor cocktail (P2714; Sigma Aldrich). Total protein extract (40 $\mu \mathrm{g}$ for silver staining or 400 $\mu \mathrm{g}$ for CBB G-250 staining) was used to rehydrate Immobiline DryStrip gels (pH 3-10 NL 18 $\mathrm{cm}$; GE Healthcare). Proteins were resolved in the first dimension by isoelectric focusing for a total of $50000 \mathrm{~V}$-h by using the Ettan IPGphor 3 (GE Healthcare). After equilibration of the strips, the second dimension was performed on 8-16\% polyacrylamide gradient gels $(20 \mathrm{~cm} \times 18$ $\mathrm{cm} \times 1 \mathrm{~mm}$ ) and was run on an Ettan Daltsix vertical system (GE Healthcare). The 2D gels were silver-stained (PlusOne Silver Staining kit; GE Healthcare) or dyed following the CBB G-250 staining method [19].

\section{Differential analysis of $2 D$ gel images}

2D gel images were captured by scanning silver-stained gels with an ImageScanner ${ }^{\mathrm{TM}} \mathrm{II}$ (GE Healthcare). Differential analysis was performed by using ImageMaster 2D Platinum v5.0 software (GE Healthcare) for spot detection, quantification, matching and comparative analysis. Each tissue sample was subjected to 2DE three times to minimize run-to-run variation, and each set of three gels was compared by using ImageMaster to confirm the nonappearance of statistically differential spots within the set of gels. The most representative gel (gel migration, spot definition, and spot number) of each set was used to test the influence of leucine compared with the control condition. The expression level was determined by the relative volume of each spot in the gel and expressed as \%volume, calculated as spot volume/ volumes of all spots 
96

97

98

99

100

101

102

103

104

105

106

107

108

109

110

111

112

113

114

115

116

117

118

resolved in the gel. Variations in abundance were calculated as the ratio of average values of \%volume for a group of spots between the two conditions. Only spots with a \%volume variation ratio greater than 1.5 were considered relevant. The corresponding $P$ values were determined by using the Student's $t$ test (significance level $P<0.05$ ) after spot \%volume log-transformation.

\section{Protein identification by LC-ESI-MS/MS}

The protein spots of interest were excised from CBB-stained 2D gels by using the Ettan Spot Picker (GE Healthcare), and automated in-gel digestion of proteins was performed on the Ettan Digester (GE Healthcare) as previously described [19]. Peptide extracts were then resuspended in $10 \mu \mathrm{L}$ of $5 \%$ (vol:vol) acetonitrile/0.1\% (vol:vol) formic acid and then analyzed with a nano-LC1200 system coupled to a 6340 Ion Trap mass spectrometer equipped with a nanospray source and an HPLC-chip cube interface (Agilent Technologies). Briefly, peptides were enriched and desalted on a $40 \mathrm{~nL}$ RP-C18 trap column and separated on a Zorbax (30-nm pore size, $5-\mu \mathrm{m}$ particle size) C18 column (43 mm long x $75 \mu \mathrm{m}$ inner diameter; Agilent Technologies). A 9-min linear gradient (3\%-80\% acetonitrile in $0.1 \%$ formic acid) at a flow rate of $400 \mathrm{~nL} / \mathrm{min}$ was used, and the eluent was analyzed with an Ion Trap mass spectrometer as previously described [20].

For protein identification, MS/MS peak lists were extracted and compared with the protein databases by using the MASCOT Daemon version 2.2.2 (Matrix Science) search engine. The searches were performed with the following specific parameters: enzyme specificity, trypsin; one missed cleavage permitted; no fixed modifications; variable modifications, methionine oxidation, cysteine carbamidomethylation, serine, tyrosine and threonine phosphorylation; monoisotopic; peptide charge, 2+ and 3+; mass tolerance for precursor ions, $1.5 \mathrm{Da}$; mass tolerance for 
119 fragment ions, 0.6 Da; ESI-TRAP as instrument; taxonomy, human; database, UniProtKB/Swiss-

120 Prot v55.6 (390696 sequences; 140503634 residues). Protein hits were automatically validated if

121 they satisfied one of the following criteria: identification with at least two top ranking peptides

122 (bold and red) each with a MASCOT score of more than $49(P<0.01)$, or at least two top

123 ranking peptides (bold and red) each with a MASCOT score of more than $42(P<0.05)$. To

124 evaluate false-positive rates, all the initial database searches were performed using the "decoy"

125 option of MASCOT. Results were considered relevant if the false-positive rate never exceeded

$1261 \%$.

127

128

Western blotting analysis

129

Total protein extracts $(20 \mu \mathrm{g})$ were resolved in 4-20\% SDS-PAGE gels and

130 electrotransferred onto nitrocellulose membrane (GE Healthcare) as previously described [19].

131 After transfer, membranes were soaked in TBS-T solution [10 mmol Tris-HCl/L pH 7.4, 150

$132 \mathrm{mmol} \mathrm{NaCl} / \mathrm{L}, 0.2 \%$ (vol:vol) Tween 20] with 3\% (wt:vol) BSA for $2 \mathrm{~h}$ at room temperature.

133 Blots were washed three times for 10 min with TBS-T and subsequently incubated overnight at

$1344^{\circ} \mathrm{C}$ in $\mathrm{TBS}-\mathrm{T}$ and $3 \%$ (wt:vol) $\mathrm{BSA}$ with various specific primary antibodies (Santa Cruz

135 Biotechnology): rabbit polyclonal antibodies anti-CPT2 (sc-130730, 1:200) or anti-OTC (sc-

136 102051, 1:200); goat polyclonal antibodies anti-ACADVL (sc-74900, 1:2000), anti-DHA kinase

137 (sc-161516, 1:2000), anti-FABP1 (sc-16064, 1:1500), anti-NDRG1 (sc-19464, 1:500) or anti-

138 HADHA (sc-82185, 1:1500). Membranes were washed three times for 10 min with TBS-T,

139 incubated with horseradish peroxidase-conjugated donkey anti-goat (sc-2020, 1:5000; Santa

140 Cruz Biotechnology) or swine anti-rabbit (P0399, 1:5000; Dako) IgG for $1 \mathrm{~h}$ at room

141 temperature, and then washed four times in TBS-T. Immunocomplexes were revealed by using 
142 the ECL detection system (GE Healthcare). Protein bands were quantified by densitometry using

143 ImageScanner III and ImageQuant TL software (GE Healthcare). The blots were reprobed with a

144 mouse anti- $\beta$-actin monoclonal antibody (A5441; $1: 5000$; Sigma Aldrich) as a loading control.

145

146

Gene Ontology

147 eGOnv2.0 software was used to annotate proteins with Gene Ontology terms. eGOn used

148 a two-sided Fisher's exact test to determine whether any GO categories were significantly

149 enriched in proteins that had been identified as being altered by leucine supplementation $(\mathrm{p}<$ $150 \quad 0.05)$.

151

152 Statistical analysis

153 The results are expressed as mean \pm SEMs and were compared by using GraphPad Prism 5.0 (GraphPad Software Inc). To evaluate the effects of leucine, statistical analysis were assessed 155 using non parametric Wilcoxon test or Student's $t$ test for paired data. For all, $P<0.05$ was 156 considered significant.

157 
158

159

160

161

162

163

164

165

166

167

168

169

170

171

172

173

174

175

176

177

178

179

\section{RESULTS}

\section{Leucine infusion modified human duodenal mucosal proteome}

In both groups, approximately 2250 protein spots per gel were detected within a $\mathrm{p} I$ range of 3 to10 and a relative molecular mass range of 10-180 kDa (Figure 1). Eleven protein spots were differentially (i.e. at least \pm 1.5 fold modulated) and significantly (Student's $t$ test, $P<0.05$ ) regulated in response to enteral leucine supplementation (Figure 1): the expression of 7 protein spots was reduced, whereas the expression of 4 other protein spots was increased. These protein spots were analyzed by using liquid chromatography coupled with electron spray ionization MS/MS, and 10 spots were identified (Table 1), whereas spot numbered 10 remained undetermined. Among the identified proteins, 7 proteins were downregulated after enteral leucine supplementation (Table 1): Trifunctional enzyme subunit alpha (HADHA, spot 1, Figure 2), Carnitine O-palmitoyltransferase 2 (CPT2, spot 2, Figure 2), Acyl-Coenzyme A dehydrogenase very long-chain (ACADVL, spot 3, Figure 2), ATP-dependant dihydroxyacetone kinase (DHA kinase, spot 4, Figure 2), N-myc downstream-regulated gene 1 protein (NDRG1, spot 5), Ornithine carbamoyltransferase (OTC, spot 7), and Sulfotransferase 1A1 (SULT1A1, spot 8). Three proteins were upregulated after enteral leucine supplementation (Table 1): gastricsin precursor (PGC, spot 6), carbonic anhydrase 1 (CA1, spot 9), and Fatty acid-binding protein liver (FABP1, spot 11).

To further support protein identification and substantiate their semiquantitative expression levels under control and leucine conditions, antibodies against ACADVL, CPT2, DHA kinase, FABP1, HADHA, NDRG1 and OTC were used for western blotting after 
180 separation of duodenal mucosal biopsy extracts by SDS-PAGE. These data confirmed the results

181 given by 2D gels and liquid chromatography-tandem mass spectrometry (Figure 3).

182

183

184

185

186

187

188

189

190

191

192

193

194

\section{Biological significance of the leucine-modulated proteins}

Using the gene ontology tool eGOn v2.0 [21] and UniProt, all the proteins identified by mass spectrometry were assigned to different categories. Each protein was categorized based on molecular function, biological process and cellular component. When grouped according to molecular function, most of the identified proteins ( 8 proteins) were involved in catalytic processes, and 7 proteins were binding proteins. Classification based on biological process revealed that 4 leucine-modulated proteins were implicated in lipid metabolic process: HADHA, CPT2 and ACADVL occur notably in the fatty acid beta-oxidation whereas FABP1 plays a role in intracellular lipid transport. Other identified proteins were involved in glycerol and xenobiotics metabolism, cell growth and differentiation, proteolysis, urea cycle, and $\mathrm{CO}_{2}$ transport (Table 1). Classification based on cellular component revealed that 4 proteins were located in mitochondria: HADHA, CPT2, ACADVL and OTC. 


\section{DISCUSSION}

In the current study, we showed that supplementation of maltodextrins with leucine altered the duodenal mucosal proteome by regulating the expression of several enzymes mainly involved in the metabolism of lipids and glycerol (Figure 4).

Leucine supplementation significantly decreased CPT2, ACADVL and HADHA expression in human duodenal mucosa suggesting that leucine may impair intestinal fatty acid oxidation (FAO). Intestinal FAO is a key metabolic pathway that contributes to energy homeostasis for intestinal cells but also to organism metabolic homeostasis. Indeed, even if fatty acids may be a source of energy for human enterocytes [22-24], the regulation of intestinal FAO participates to organism response to food ingestion. Interestingly, the capacity of lipid catabolism in the small intestine was higher in obesity-resistant mice [25] and the stimulation of intestinal FAO after ingestion of either $\alpha$-linolenic acid rich diacylglycerols [26] or fish oil [27] was associated with body weight loss.

We speculate that the regulation of intestinal FAO by leucine may be a key issue to better understand the effects of leucine on whole body. By limiting intestinal FAO, leucine may contribute to increase postprandial lipidemia and thus fatty acid disposal for peripheral tissues. Leucine supplementation has been proposed as a potential therapeutic strategy to prevent obesity [28] or sarcopenia of aging [29, 30]. Nevertheless, contradictory data were reported concerning the effect of long-term supplementation with leucine on body composition. Indeed, long-term leucine supplementation decreased fat mass in high fat diet-induced obese mice [28, 31] and in aging rats [32]. Nairizi et al. showed that leucine supplementation of drinking water did not alter body composition or adiposity of mice fed with a high-fat diet [33]. Similarly, 3 months of 
218 leucine supplementation affected neither fat mass nor skeletal muscle mass in healthy elderly

219 men [34]. More recently, Zeanandin et al reported that long-term dietary leucine excess

220 promoted hypertrophy and hyperplasia of adipose tissue in old rats, whereas skeletal muscle

221 mass was not changed [35]. In this latter study, perirenal adipose tissue weight was increased by $22245 \%$.

To our knowledge, our study shows for the first time that leucine may limit intestinal

224 FAO in humans and suggests that leucine may differentially affect fatty acid metabolism in different tissues. Indeed, in NCI-H716 intestinal cells, leucine downregulated the expression of genes involved in the absorption or synthesis of fatty acids or cholesterol [36]. In contrast, longterm leucine supplementation stimulated the expression of key genes involved in fatty acid metabolism in skeletal muscle of obese mice associated with increased energy expenditure [37]. In the same way, leucine enhanced FAO in $\mathrm{C} 2 \mathrm{C} 12$ muscle cells while it reduced fatty acid synthase gene expression in 3T3-L1 adipocytes [38]. It was also reported that lipolysis and expression of $\beta$-oxidation genes were significantly increased in white adipose tissue of C57BL/6J mice fed for 7 days with leucine-deficient diet [39]. However, in the present study, we only

233 reported the effects of leucine on the expression of enzymes involved in FAO but we did not assess their activities. Further studies should evaluate intestinal FAO in leucine-supplemented 235 subjects. human duodenal mucosa (Figure 3). NDRG1, which is strongly expressed in the human small intestine and epithelial cells [40, 41], is involved in stress responses [42, 43], apoptosis [44], 240 allergic responses [45], cell growth and differentiation [46]. In mouse embryonic fibroblast cells, mRNA level of NDRG1 was up-regulated in response to leucine starvation [47]. We recently 
242 showed that enteral leucine supplementation enhanced intestinal cell proliferation through the

$243 \mathrm{PI}$ KK/Akt/GSK-3 $\alpha / \beta$-catenin pathway in healthy humans [18]. The decrease of NDRG1 observed

244 in the present study may also contribute to the enhancement of cell proliferation. Zhang et al

245 reported that polyamine depletion increased the expression of NDRG1 and finally inhibited

246 intestinal epithelial cell proliferation [48]. In our study, we can speculate that polyamine

247 synthesis in intestinal cells may be increased after leucine supplementation since we observed a

248 reduction of OTC expression (Figure 3), ornithine carbamoyltransferase that catalyzes the

249 conversion of ornithine into citrulline. Consequently to the decrease of OTC, ornithine may be

250 either used for polyamine synthesis or exported to portal vein. Accordingly, Mouillé et al

251 previously showed a decrease of ornithine utilization for citrulline synthesis in rat colonocytes

252 after hyperproteic diet [49]. It is well established that polyamines regulate intestinal cell

253 proliferation [50]. All these data suggest that the decreased expressions of NDRG1 and OTC

254 induced by leucine in the present study may contribute to the enhancement of intestinal cell

255 proliferation, previously reported after leucine supplementation [18].

256

257

In conclusion, leucine supplementation altered the expression of several duodenal mucosal proteins, which are mainly involved in lipid metabolism. Leucine supplementation may

259 slowdown fatty acid $\beta$-oxidation in duodenal mucosa. Further investigations are needed to

260 evaluate whether reduction of intestinal fatty acid $\beta$-oxidation by leucine may contribute to 261 regulate whole body metabolic homeostasis and body composition. 


\section{ACKNOWLEDGMENTS}

We thank the staffs of the Clinical Investigation Center (CIC 0204) and the Endoscopy 266 Unit for their assistance with volunteer inclusion and infusion procedures and with the 267 endoscopic procedure, respectively. This study was support by the French Agency for Research 268 (Agence Nationale pour la Recherche, ANR-07-PNRA-020), the Nutricia Research Foundation 269 and the Benjamin Delessert Institute.

The funders of this study did not interfere in the design, implementation, analysis, or interpretation of the data. None of the authors declared a conflict of interest.

\section{ABBREVIATIONS}

ACADVL, Acyl-Coenzyme A dehydrogenase very long-chain; CA1, Carbonic anhydrase 1; kinase; FABP1, Fatty acid-binding protein liver; FAO, fatty acid oxidation; HADHA, precursor; SULT1A1, Sulfotransferase 1A1. 


\section{REFERENCES}

[1] Nylund CM, D'Mello S, Kim MO, Bonkowski E, Däbritz J, Foell D, Meddings J, Trapnell BC, Denson LA. Granulocyte macrophage-colony-stimulating factor autoantibodies and increased intestinal permeability in Crohn disease. J Pediatr Gastroenterol Nutr 2011;52:5428.

[2] Wapenaar MC, Monsuur AJ, van Bodegraven AA, Weersma RK, Bevova MR, Linskens RK, Howdle P, Holmes G, Mulder CJ, Dijkstra G, et al. Associations with tight junction genes PARD3 and MAGI2 in Dutch patients point to a common barrier defect for coeliac disease and ulcerative colitis. Gut 2008;57:463-7.

[3] Turner JR. Intestinal mucosal barrier function in health and disease. Nat Rev Immunol 2009;9:799-809.

[4] Coeffier M, Claeyssens S, Hecketsweiler B, Lavoinne A, Ducrotte P, Dechelotte P. Enteral glutamine stimulates protein synthesis and decreases ubiquitin mRNA level in human gut mucosa. Am J Physiol Gastrointest Liver Physiol 2003;285:G266-73.

[5] Xi P, Jiang Z, Dai Z, Li X, Yao K, Zheng C, Lin Y, Wang J, Wu G. Regulation of protein turnover by l-glutamine in porcine intestinal epithelial cells. J Nutr Biochem 2011; DOI: 10.1016/j.jnutbio.2011.05.009.

[6] Le Bacquer O, Laboisse C, Darmaun D. Glutamine preserves protein synthesis and paracellular permeability in caco-2 cells submitted to "luminal fasting". Am J Physiol Gastrointest Liver Physiol 2003;285:G128-36.

[7] Boukhettala N, Claeyssens S, Bensifi M, Maurer B, Abed J, Lavoinne A, Dechelotte P, Coeffier M. Effects of essential amino acids or glutamine deprivation on intestinal 
permeability and protein synthesis in het-8 cells: Involvement of gen2 and mtor pathways. Amino Acids 2012;42:375-83.

[8] Bauchart-Thevret C, Cui L, Wu G, Burrin DG. Arginine-induced stimulation of protein synthesis and survival in PIEC-J2 cells is mediated by mTOR but not nitric oxide. Am J Physiol Endocrinol Metab 2010;299:E899-909.

[9] Corl BA, Odle J, Niu X, Moeser AJ, Gatlin LA, Phillips OT, Blikslager AT, Rhoads JM. Arginine activates intestinal $\mathrm{p} 70(\mathrm{~s} 6 \mathrm{k})$ and protein synthesis in piglet rotavirus enteritis. J Nutr 2008;138:24-9.

[10] Suryawan A, Torrazza RM, Gazzaneo MC, Orellana RA, Fiorotto ML, El-Kadi SW, Srivastava N, Nguyen HV, Davis TA. Enteral leucine supplementation increases protein synthesis in skeletal and cardiac muscles and visceral tissues of neonatal pigs through mTORC1-dependent pathways. Pediatr Res 2012;71:324-31.

[11] Casperson SL, Sheffield-Moore M, Hewlings SJ, Paddon-Jones D. Leucine supplementation chronically improves muscle protein synthesis in older adults consuming the RDA for protein. Clin Nutr 2012; DOI: 10.1016/j.clnu.2012.01.005.

[12] Combaret L, Dardevet D, Rieu I, Pouch MN, Béchet D, Taillandier D, Grizard J, Attaix D. A leucine-supplemented diet restores the defective postprandial inhibition of proteasomedependent proteolysis in aged rat skeletal muscle. J Physiol 2005;569:489-99.

[13] Ban H, Shigemitsu K, Yamatsuji T, Haisa M, Nakajo T, Takaoka M, Nobuhisa T, Gunduz M, Tanaka N, Naomoto Y. Arginine and leucine regulate p70 S6 kinase and 4E-BP1 in intestinal epithelial cells. Int J Mol Med 2004;13:537-43.

[14] Nakajo T, Yamatsuji T, Ban H, Shigemitsu K, Haisa M, Motoki T, Noma K, Nobuhisa T, Matsuoka J, Gunduz M, et al. Glutamine is a key regulator for amino acid-controlled cell 
growth through the mTOR signaling pathway in rat intestinal epithelial cells. Biochem Biophys Res Commun 2005;326:174-80.

[15] Rhoads JM, Liu Y, Niu X, Surendran S, Wu G. Arginine stimulates cdx2-transformed intestinal epithelial cell migration via a mechanism requiring both nitric oxide and phosphorylation of p70 s6 kinase. J Nutr 2008;138:1652-7.

[16] Murgas Torrazza R, Suryawan A, Gazzaneo MC, Orellana RA, Frank JW, Nguyen HV, Fiorotto ML, El-Kadi S, Davis TA. Leucine supplementation of a low-protein meal increases skeletal muscle and visceral tissue protein synthesis in neonatal pigs by stimulating mtordependent translation initiation. J Nutr 2010;140:2145-52.

[17] Yin Y, Yao K, Liu Z, Gong M, Ruan Z, Deng D, Tan B, Wu G. Supplementing L-leucine to a low-protein diet increases tissue protein synthesis in weanling pigs. Amino Acids 2010;39:1477-86.

[18] Coëffier M, Claeyssens S, Bensifi M, Lecleire S, Boukhettala N, Maurer B, Donnadieu N, Lavoinne A, Cailleux AF, Déchelotte P. Influence of leucine on protein metabolism, phospho-kinase expression and cell proliferation in human duodenum. Am J Clin Nutr 2011;93:1255-62.

[19] Goichon A, Coëffier M, Claeyssens S, Lecleire S, Cailleux AF, Bôle-Feysot C, Chan P, Donnadieu N, Lerebours E, Lavoinne A,et al. Effects of an enteral glucose supply on protein synthesis, proteolytic pathways, and proteome in human duodenal mucosa. Am J Clin Nutr 2011;94:784-94.

[20] Elias S, Delestre C, Ory S, Marais S, Courel M, Vazquez-Martinez R, Bernard S, Coquet L, Malagon MM, Driouich A, Chan P, Gasman S, Anouar Y, Montero-Hadjadje M. 
Chromogranin a induces the biogenesis of granules with calcium- and actin-dependent dynamics and exocytosis in constitutively secreting cells. Endocrinology 2012;153:4444-56.

[21] Ashburner M, Ball CA, Blake JA, Botstein D, Butler H, Cherry JM, Davis AP, Dolinski K, Dwight SS, Eppig JT, et al. Gene ontology: tool for the unification of biology. The Gene Ontology Consortium. Nat Genet 2000;25:25-9.

[22] Montoudis A, Seidman E, Boudreau F, Beaulieu JF, Menard D, Elchebly M, Mailhot G, Sane AT, Lambert M, Delvin E, et al. Intestinal fatty acid binding protein regulates mitochondrion beta-oxidation and cholesterol uptake. J Lipid Res 2008;49:961-72.

[23] D'Errico I, Salvatore L, Murzilli S, Lo Sasso G, Latorre D, Martelli N, Egorova AV, Polishuck R, Madeyski-Bengtson K, Lelliott C, et al. Peroxisome proliferator-activated receptor-gamma coactivator 1-alpha (PGC1alpha) is a metabolic regulator of intestinal epithelial cell fate. Proc Natl Acad Sci USA 2011;108:6603-8.

[24] Kimura R, Takahashi N, Murota K, Yamada Y, Niiya S, Kanzaki N, Murakami Y, Moriyama T, Goto T, Kawada T. Activation of peroxisome proliferator-activated receptor- $\alpha$ $(\operatorname{PPAR} \alpha)$ suppresses postprandial lipidemia through fatty acid oxidation in enterocytes. Biochem Biophys Res Commun 2011;410:1-6.

[25] Kondo H, Minegishi Y, Komine Y, Mori T, Matsumoto I, Abe K, Tokimitsu I, Hase T, Murase T. Differential regulation of intestinal lipid metabolism-related genes in obesityresistant A/J vs. obesity-prone C57BL/6J mice. Am J Physiol Endocrinol Metab 2006;291:E1092-9.

[26] Murase T, Aoki M, Wakisaka T, Hase T, Tokimitsu I. Anti-obesity effect of dietary diacylglycerol in $\mathrm{C} 57 \mathrm{BL} / 6 \mathrm{~J}$ mice: dietary diacylglycerol stimulates intestinal lipid metabolism. J Lipid Res 2002;43:1312-9. 
[27] Mori T, Kondo H, Hase T, Tokimitsu I, Murase T. Dietary fish oil upregulates intestinal lipid metabolism and reduces body weight gain in C57BL/6J mice. J Nutr 2007;137: 262934.

[28] Zhang Y, Guo K, LeBlanc RE, Loh D, Schwartz GJ, Yu YH. Increasing dietary leucine intake reduces diet-induced obesity and improves glucose and cholesterol metabolism in mice via multimechanisms. Diabetes 2007;56:1647-54.

[29] Katsanos CS, Kobayashi H, Sheffield-Moore M, Aarsland A, Wolfe RR. A high proportion of leucine is required for optimal stimulation of the rate of muscle protein synthesis by essential amino acids in the elderly. Am J Physiol Endocrinol Metab 2006;291:E381-7.

[30] Rieu I, Balage M, Sornet C, Giraudet C, Pujos E, Grizard J, Mosoni L, Dardevet D. Leucine supplementation improves muscle protein synthesis in elderly men independently of hyperaminoacidaemia. J Physiol 2006;575:305-15.

[31] Macotela Y, Emanuelli B, Bång AM, Espinoza DO, Boucher J, Beebe K, Gall W, Kahn CR. Dietary leucine--an environmental modifier of insulin resistance acting on multiple levels of metabolism. PLoS One 2011;6:e21187.

[32] Vianna D, Resende GF, Torres-Leal FL, Pantaleão LC, Donato J Jr, Tirapegui J. Longterm leucine supplementation reduces fat mass gain without changing body protein status of aging rats. Nutrition 2012;28:182-9.

[33] Nairizi A, She P, Vary TC, Lynch J. Leucine supplementation of drinking water does not alter susceptibility to diet-induced obesity in mice. J Nutr 2009;139:715-9. 
[34] Verhoeven S, Vanschoonbeek K, Verdijk LB, Koopman R, Wodzig WK, Dendale P, van Loon LJ. Long-term leucine supplementation does not increase muscle mass or strength in healthy elderly men. Am J Clin Nutr 2009;89:1468-75.

[35] Zeanandin G, Balage M, Schneider SM, Dupont J, Hébuterne X, Mothe-Satney I, Dardevet D. Differential effect of long-term leucine supplementation on skeletal muscle and adipose tissue in old rats: an insulin signaling pathway approach. Age (Dordr) 2012;34:37187.

[36] Chen Q, Reimer RA. Dairy protein and leucine alter GLP-1 release and mRNA of genes involved in intestinal lipid metabolism in vitro. Nutrition 2009;25:340-9.

[37] Guo K, Yu YH, Hou J, Zhang Y. Chronic leucine supplementation improves glycemic control in etiologically distinct mouse models of obesity and diabetes mellitus. Nutr Metab (Lond) 2010;7:57.

[38] Sun X, Zemel MB. Leucine and calcium regulate fat metabolism and energy partitioning in murine adipocytes and muscle cells. Lipids 2007;42:297-305.

[39] Cheng Y, Meng Q, Wang C, Li H, Huang Z, Chen S, Xiao F, Guo F. Leucine deprivation decreases fat mass by stimulation of lipolysis in white adipose tissue and upregulation of uncoupling protein 1 (UCP1) in brown adipose tissue. Diabetes 2010;59:17-25.

[40] Lachat P, Shaw P, Gebhard S, van Belzen N, Chaubert P, Bosman FT. Expression of NDRG1, a differentiation-related gene, in human tissues. Histochem Cell Biol 2002;118:399408.

[41] Yaylaoglu MB, Agbemafle BM, Oesterreicher TJ, Finegold MJ, Thaller C, Henning SJ. Diverse patterns of cell-specific gene expression in response to glucocorticoid in the developing small intestine. Am J Physiol Gastrointest Liver Physiol 2006;291:G1041-50. 
[42] Salnikow K, Kluz T, Costa M, Piquemal D, Demidenko ZN, Xie K, Blagosklonny MV. The regulation of hypoxic genes by calcium involves c-Jun/AP-1, which cooperates with hypoxia-inducible factor 1 in response to hypoxia. Mol Cell Biol 2002; 22:1734-41.

[43] Toffoli S, Delaive E, Dieu M, Feron O, Raes M, Michiels C. NDRG1 and CRK-I/II are regulators of endothelial cell migration under Intermittent Hypoxia. Angiogenesis 2009;12:339-54.

[44] Stein S, Thomas EK, Herzog B, Westfall MD, Rocheleau JV, Jackson RS 2nd, Wang M, Liang P. NDRG1 is necessary for p53-dependent apoptosis. J Biol Chem 2004;279:4893040.

[45] Taketomi Y, Sunaga K, Tanaka S, Nakamura M, Arata S, Okuda T, Moon TC, Chang HW, Sugimoto Y, Kokame K, et al. Impaired mast cell maturation and degranulation and attenuated allergic responses in Ndrg1-deficient mice. J Immunol 2007;178:7042-53.

[46] Piquemal D, Joulia D, Balaguer P, Basset A, Marti J, Commes T. Differential expression of the RTP/Drg1/Ndr1 gene product in proliferating and growth arrested cells. Biochim Biophys Acta 1999;1450:364-73.

[47] Deval C, Chaveroux C, Maurin AC, Cherasse Y, Parry L, Carraro V, Milenkovic D, Ferrara M, Bruhat A, Jousse C, et al. Amino acid limitation regulates the expression of genes involved in several specific biological processes through GCN2-dependent and GCN2independent pathways. FEBS J 2009;276:707-18.

[48] Zhang AH, Rao JN, Zou T, Liu L, Marasa BS, Xiao L, Chen J, Turner DJ, Wang JY. p53-dependent NDRG1 expression induces inhibition of intestinal epithelial cell proliferation but not apoptosis after polyamine depletion. Am J Physiol Cell Physiol 2007;293:C379-89. 
[49] Mouillé B, Robert V, Blachier F. Adaptative increase of ornithine production and decrease of ammonia metabolism in rat colonocytes after hyperproteic diet ingestion. Am J Physiol Gastrointest Liver Physiol 2004;287:G344-51.

[50] Liu L, Li L, Rao JN, Zou T, Zhang HM, Boneva D, Bernard MS, Wang JY. Polyamine modulated expression of c-myc plays a critical role in stimulation of normal intestinal epithelial cell proliferation. Am J Physiol Cell Physiol 2005;288:C89-99. 
TABLE:

Table 1. Human duodenal mucosal proteome changes in response to leucine infusion ${ }^{1}$

\begin{tabular}{|c|c|c|c|c|c|c|c|c|c|}
\hline \multirow{2}{*}{$\begin{array}{c}\text { Spot } \\
\text { number }\end{array}$} & \multirow{2}{*}{$\begin{array}{c}\text { Swiss-Prot } \\
\text { accession } \\
\text { number }\end{array}$} & \multirow{2}{*}{ Protein name } & \multirow{2}{*}{$\begin{array}{l}\text { Biological } \\
\text { process }\end{array}$} & \multicolumn{2}{|c|}{ Theoretical } & \multirow{2}{*}{$\begin{array}{c}\text { Fold } \\
\text { change }^{2}\end{array}$} & \multirow{2}{*}{$\begin{array}{l}\text { Score on } \\
\text { MASCOT }\end{array}$} & \multirow{2}{*}{$\begin{array}{c}\text { Sequence } \\
\text { coverage } \\
(\%)\end{array}$} & \multirow{2}{*}{$\begin{array}{l}\text { Peptide } \\
\text { hit }\end{array}$} \\
\hline & & & & $\mathrm{p} I$ & $\begin{array}{c}M r \\
(\mathrm{kDa})\end{array}$ & & & & \\
\hline 1 & P40939 & $\begin{array}{l}\text { Trifunctional enzyme subunit alpha } \\
\text { (HADHA) }\end{array}$ & $\begin{array}{l}\text { Lipid } \\
\text { metabolism }\end{array}$ & 9.16 & 82.9 & -1.63 & 82 & 4 & 3 \\
\hline 2 & P23786 & $\begin{array}{c}\text { Carnitine O-palmitoyltransferase } 2 \\
\text { (CPT2) }\end{array}$ & $\begin{array}{l}\text { Lipid } \\
\text { metabolism }\end{array}$ & 8.38 & 73.7 & -1.75 & 166 & 8 & 4 \\
\hline 3 & P49748 & $\begin{array}{l}\text { Acyl-Coenzyme A dehydrogenase } \\
\text { very long-chain (ACADVL) }\end{array}$ & $\begin{array}{c}\text { Lipid } \\
\text { metabolism }\end{array}$ & 8.92 & 70.3 & -1.76 & 132 & 5 & 3 \\
\hline 4 & Q3LXA3 & $\begin{array}{l}\text { ATP-dependant dihydroxyacetone } \\
\text { kinase (DHA Kinase) }\end{array}$ & $\begin{array}{l}\text { Glycerol } \\
\text { metabolism }\end{array}$ & 7.12 & 58.9 & -1.51 & 321 & 25 & 10 \\
\hline 5 & Q92597 & Protein NDRG1 & Cell growth & 5.49 & 42.8 & -1.51 & 159 & 11 & 3 \\
\hline 6 & P20142 & Gastricsin precursor (PGC) & Proteolysis & 4.36 & 42.4 & +1.98 & 103 & 3 & 2 \\
\hline 7 & P00480 & Ornithine carbamoyltransferase (OTC) & Urea cycle & 8.75 & 39.9 & -1.52 & 282 & 24 & 10 \\
\hline 8 & P50225 & Sulfotransferase 1A1 (SULT1A1) & $\begin{array}{l}\text { Xenobiotics } \\
\text { metabolism }\end{array}$ & 6.16 & 34.2 & -1.57 & 66 & 9 & 3 \\
\hline 9 & P00915 & Carbonic anhydrase 1 (CA1) & $\mathrm{CO}_{2}$ transport & 6.59 & 28.9 & +1.98 & 195 & 24 & 6 \\
\hline 10 & - & Undetermined & - & - & - & +1.56 & - & - & - \\
\hline 11 & P07148 & $\begin{array}{l}\text { Fatty acid-binding protein liver } \\
\text { (FABP1) }\end{array}$ & $\begin{array}{c}\text { Lipid } \\
\text { metabolism }\end{array}$ & 6.60 & 14.2 & +1.88 & 86 & 25 & 2 \\
\hline
\end{tabular}


${ }^{1}$ MASCOT, algorithm that uses mass spectrometric data to identify proteins from primary sequence databases; $M r$, molar mass; $\mathrm{p} I$, isoelectric point.

${ }^{2}+$, upregulated; - , downregulated. 


\section{FIGURE LEGENDS:}

Figure 1. Silver-stained 2-dimensional gel images representing total proteins extracted from human duodenal mucosal biopsy samples after maltodextrins (A) and leucinesupplemented maltodextrins (B) enteral perfusion. Differentially expressed proteins (ie, at least \pm 1.5 fold modulated; circled spots with a number) were determined by statistical analysis (Paired Student's $t$ test, $P<0.05$ ) and correspond to the samples analyzed by liquid chromatography-tandem mass spectrometry. Protein identification results are depicted in Table 1.

Figure 2. Effects of leucine supplementation on the expression of four duodenal mucosal proteins involved in fatty acid or glycerol metabolism. A: Representative enlargements of silver-stained 2-dimensional gels issued from healthy subjects infused enterally with maltodextrins (Control) or leucine-supplemented maltodextrins (Leucine) showing 4 differentially expressed proteins. The circles represent the expression of HADHA (spot 1), CPT2 (spot 2), ACADVL (spot 3) and DHA Kinase (spot 4) in control and leucine conditions, respectively. These proteins were downregulated after $5 \mathrm{~h}$ of enteral leucine supplementation. B: HADHA, CPT2, ACADVL and DHA kinase expression levels are shown for the control and leucine groups. The display values for graphs are means \pm SEMs; $n=5$. *Significantly different from control group, $P<0.05$ (Paired Student's $t$ test).

Figure 3. Effects of leucine supplementation on ACADVL, CPT2, DHA kinase, FABP1, HADHA, NDRG1 and OTC expression in human duodenal mucosa. Representative 
immunoblots (A) and densitometric analysis of ACADVL, CPT2, DHA kinase, FABP1, HADHA, NDRG1 and OTC expression (B) in duodenal mucosa of healthy volunteers after $5 \mathrm{~h}$ of enteral maltodextrins alone (control) or with leucine supplementation. Values are means \pm SEMs; $(n=5)$. *Significantly different from control group, $P<0.05$ (Paired Student's $t$ test). AU, arbitrary units.

Figure 4. Role of five relevant leucine-modulated proteins in lipid and glycerol metabolism. DHA Kinase plays a critical role in glycerol metabolism by converting glycerol to glycerol 3phosphate in an ATP dependent reaction. HADHA, CPT2 and ACADVL are involved in the fatty acid beta-oxidation process whereas FABP1 plays a role in intracellular fatty acid transport. Upregulated and downregulated proteins are indicated with + and - , respectively. Their intervention levels in lipid or glycerol metabolism are indicated with arrows. ACADVL, AcylCoenzyme A dehydrogenase very long-chain; CPT2, Carnitine O-palmitoyltransferase 2; DHA kinase, ATP-dependant dihydroxyacetone kinase; FABP1, Fatty acid-binding protein liver; HADHA, Trifunctional enzyme subunit alpha. 
FIGURE LEGENDS:

Figure 1




Figure 2

A

Control

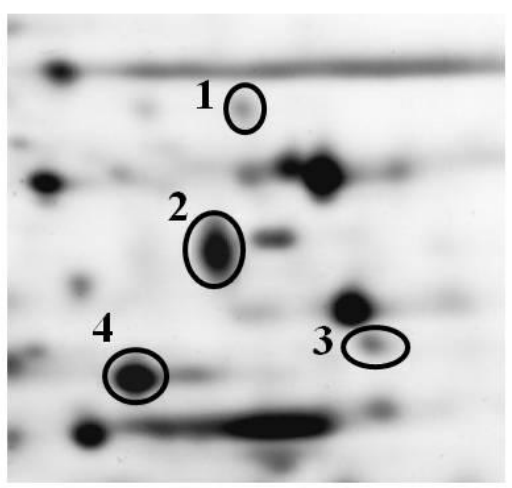

B

HADHA

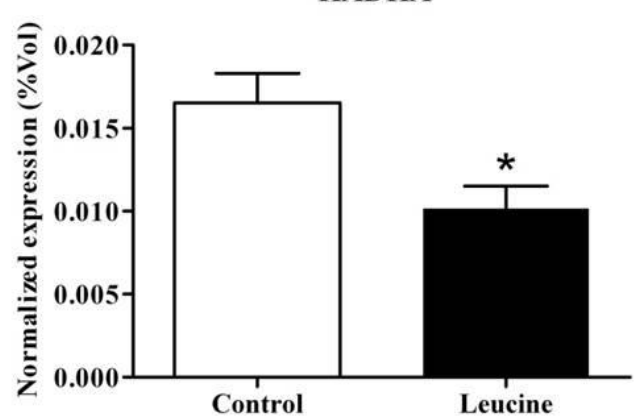

ACADVL

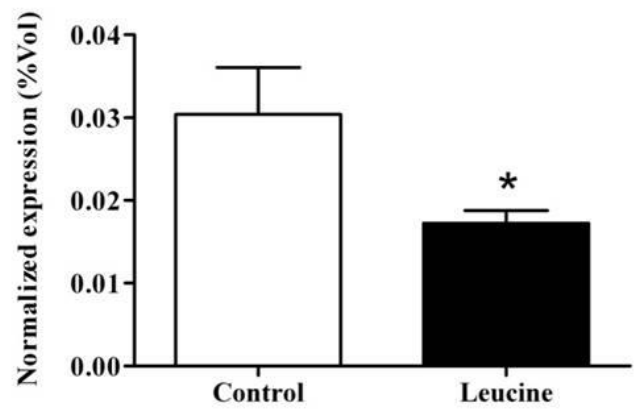

Leucine

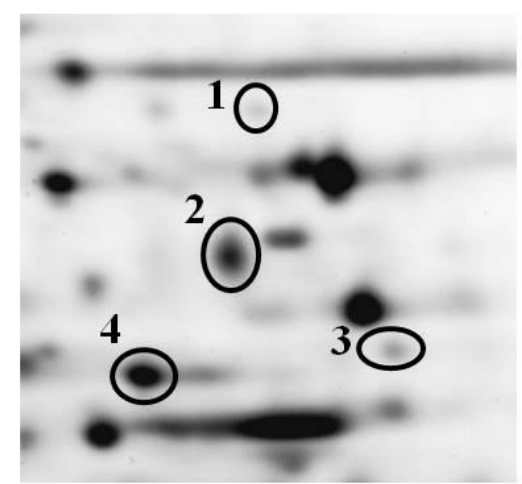

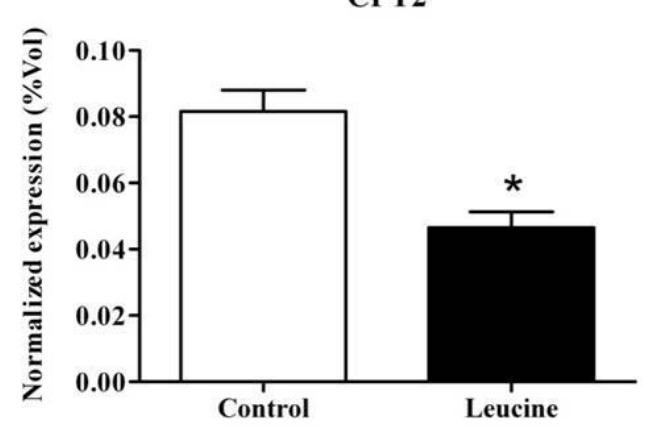

DHA Kinase

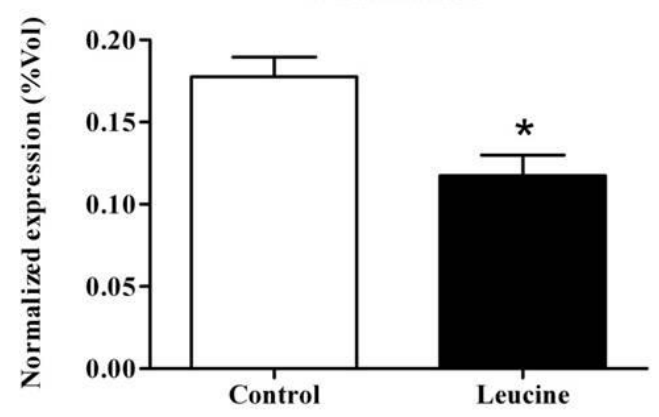


Figure 3

A

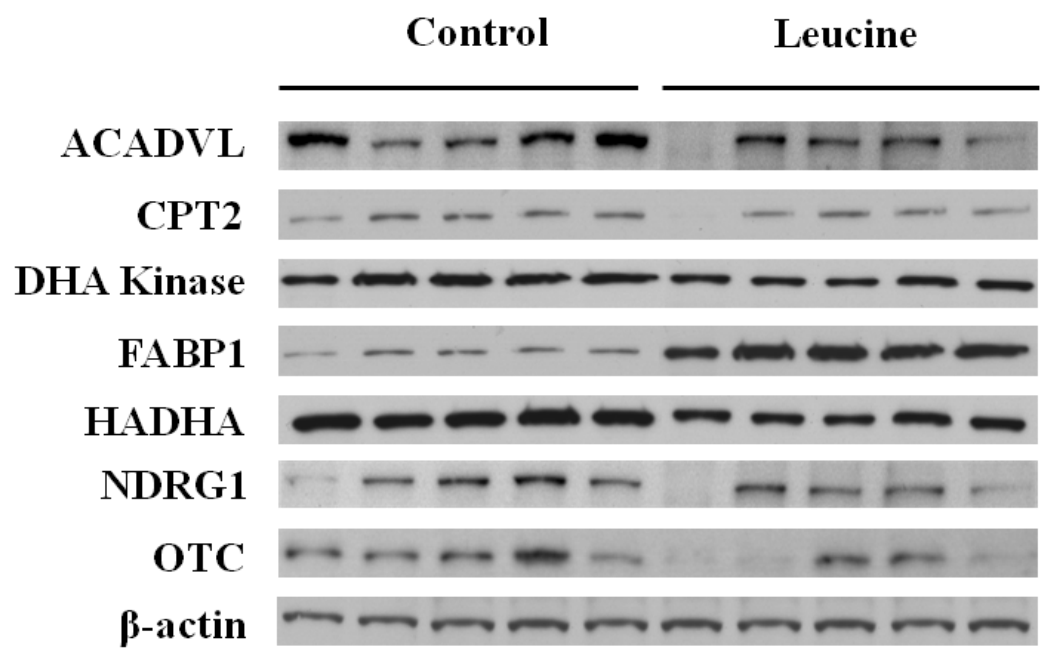

B






\section{Figure 4}



